\title{
Suffering as Expressed in the Psalter and Beyond: An Unfinished Systematic-Theological Perspective on Evolutionary "Theodicy"
}

\author{
Daniël P. Veldsman (University of Pretoria)
}

\begin{abstract}
From an evolutionary perspective, it is argued in the following exposition that specific expressions of suffering in the Psalter open up a broadened, deeper and gracious understanding of human suffering within a kind God's good creation. From the many and diverse voices of suffering as responses to diverse kinds of suffering, and if hermeneutically embedded in a post-Darwinian evolutionary framework, different existential and theological horizons of interpretation are prompted and revisited. These very horizons that interpretively open up direct us as embodied persons of flesh and blood, on the one hand, to new and other dimensions of our being vulnerable creatures before God, and on the other hand, to different glimpses of a kind creator God in a world of dynamic relationships and forces. Ultimately, embedded in a post-Darwinian evolutionary framework, the Psalter eventuates here and now, in contexts of suffering for embodied persons, a gracious cognitive-affective reappraisal of their faith.
\end{abstract}

KEYWORDS: Psalter; suffering; theodicy; Evolutionary Extended Synthesis; niche construction; re-appraisal

\section{A INTRODUCTION}

In his Love Almighty and Ills Unlimited, the English Anglican philosopher and theologian, Austin Farrer (1904-1968) poses the heart-gripping question of faith: "Poor limping world, why does not your kind Creator pull the thorn of your paw?" In that question, Farrer echoes for me the tone of many biblical psalms in Israel's worship that expresses existential and theological engagement with diverse experiences of suffering; of human suffering before their confessed

* Submitted: 17/02/2021; peer-reviewed: 16/04/2021; accepted: 23/April/2021. Daniël P. Veldsman, "Suffering as Expressed in the Psalter and Beyond: An Unfinished Systematic-Theological Perspective on Evolutionary 'Theodicy,"' Old Testament Essays 34 no. 1 (2021): 219 - 239. DOI: https://doi.org/10.17159/23123621/2021/v34n1a12.

1 Austin Farrer, Love Almighty and Ills Unlimited: An Essay on Providence and Evil, Containing the Nathaniel Taylor Lectures for 1961 (London: Collins, 1962), 114. 
Creator, a kind Creator that is called upon by the faithful since it is acknowledged from their faith relationships that the Creator is in the (almighty) position to do something about the "poor limping world" and specifically about the "thorn" in their paws. It is an echo that will be expounded and broadened in what follows and ultimately embedded within contemporary science-religion discourses. The embedded question of the echo can be posed as follow: Can an evolutionary approach help us to attain a deeper gracious understanding of human suffering within a theological context of belief in a kind Creator and Saviour God?

Since the 18th century, the question of suffering is interpretatively mostly captured in many Northern theological discourses of the concept of theodicy as was coined by the German philosopher Gottfried Leibniz in his French work with the translated title, Essays of Theodicy about the Benevolence of God, the Free Will of Man and the Origin of Evil (1710). ${ }^{2}$ Regarding the latter, it can be asked whether the concept of theodicy, which has become very influential and almost a trademark for theological questions on human suffering, is theologically appropriate and should rather be interpretively pruned or revoked? ${ }^{3}$ In this regard, it will be argued and substantiated with specific focus on the Psalter that an evolutionary approach can indeed help us to attain a deeper gracious understanding of human suffering. Firstly, the context of and motivation for my contemporary study will be indicated. Secondly, the voices of the Psalter on suffering will be discussed briefly and subsequently embedded in contemporary science-theology discourses on evolution. Lastly, a tentative effort is undertaken as directive on the one hand to revisit and revise the conceptualisation of God, and on the other hand, to expound deeper different dimensions of our being vulnerable creatures and the implications in a world of dynamic relationships and forces.

2 See Theodicy, cited 18 December 2020, online: http://www.newworldencyclopedia.org/entry/Theodicy.

3 Revoking theodicy has strong proponents. Theodicy has been called immoral, unhelpful, intellectually hubristic to mention but a few. To name but four influential "anti-theodicists": Sarah K. Pinnock, Beyond Theodicy (Albany: SUNY Press, 2002); Dewi Z. Phillips, The Problem of Evil and the Problem of God (London: SCM Press, 2004); Nicholas T. Wright, Evil and the Justice of God (Downers Grove: InterVarsityPress, 2006); John Swinton, Raging with Compassion: Pastoral Responses to the Problem of Evil (Grand Rapids: Eerdmans, 2007). For a very recent philosophical engagement with the viewpoint of an anti-theodicist, see Daylan Balfour, "Secondpersonal Theodicy: Coming to Know Why God Permits Suffering by Coming to Know God Himself," IJPR 88 (2020): 287-305. 


\section{B CONTEXT AND MOTIVATION}

\section{Context}

The present South African context - as the context from which I am addressing the question - can best be described in social-economic and existential terms of extreme turmoil, hurt, suffering, violence, poverty, criminality, corruption, displacements and disruptions, ranging from societal, collective to institutional and individual spheres. Permeating all of these spheres also are the relentless contemporary waves of the raging Covid-pandemic, dwarfing any other serious and ongoing health issues - to name but one - the AIDS pandemic or everyday incidence of severe trauma. I described in a recent publication, the relentless waves of the Covid-pandemic as follow.

The Covid-pandemic respects no boundaries. It does not differentiate between political, ideological life- and worldviews. It has a preferential option and extremely strong claws of physical-emotional soft spots for human and societal vulnerabilities. The pandemic does not respond to in isolation or respect academic fields that are pursuing anxiously and fervently its medical obliteration and philosophical sense making. Whilst we are sanitising hands and wearing masks as precaution against infection, the pandemic is, on the one hand, sanitising our misplaced mind-sets, behavioural patterns and disjointed or distorted relations, and on the other hand, unmasking shallow and cheap answers to deep anthropological values and ideologies. It unearths economic injustices, distorted and disconfirmed relationships (of power) and brutally exposes societal marginalisations. ${ }^{4}$

Misplaced mind-sets? Cheap answers? Indeed, these are key descriptive terms to engage critically with especially in reflection on suffering. Can the deep and unearthed suffering following the pandemic as described above, be questioned along the lines of the previous remark on a limping world by Farrer? Can Farrer's "thorn of your paw" sixty years later be transcendentally redescribed in terms of agency within the context of the contemporary pandemic as the Dutch philosopher Damiaan Denys does in the catchy Dutch phrase, "...een tik van de Schepper?"5 Is such a formulation (translated in English: "a slap by God") theologically meaningful and helpful? From my concrete closeness to the Cradle of Humankind with its limestone's caves (Sterkfontein

4 Daniël P. Veldsman, "God's Spirit (of Wisdom) Has Been Sent into the World, not Covid-19: A Contextual Systematic-theological Perspective," HTS Theological Studies 76 (2020): 1-2.

5 Damiaan Denys, “Tien Geboden”, Trouw (4 April 2020), [cited 5 December 2020] https://www.trouw.nl/leven/filosoof-damiaan-denys-het-coronavirus-is-een-gezondecorrectie-op-onze-megalomane-levensstijl. 
Caves and Rising Star Cave), less than 50 kilometres away from my office at the Faculty of Theology and Religion at the University of Pretoria, I would like to address the question by taking expressions of suffering within the Psalter as a point of departure, followed by an argumentative broadening of the question to a post-Darwinian evolutionary context within science-theology discourses. My aim and focus will be to move through and beyond the many and diverse voices of suffering depicted in the Psalter in order to challenge contemporary traditional (read: superficial) Christian viewpoints on suffering. ${ }^{6}$

To challenge them, since this is precisely what these various and different voices of the Psalter do, an evolutionary approach invites us to take these various voices seriously within our own contexts and within specific new interpretative frameworks, especially of vulnerability. Short-sighted theodicies have to be unmasked, not only for the sake of the credibility of our Christian faith, but also to counter the various religious immunisation strategies.

Put differently, an evolutionary approach helps us (anew) as embodied persons to see, feel, hear, and understand (read: respect) the unearthed experiences of tears, disillusionment, pain, alienation and death (in short: our vulnerability) within creation. We use the term anew, since the evolutionary approach will not only insightfully deepen and prune (revoke?) the question of theodicy, but also broaden its scope by engaging the whole of creation - thus ,not only focusing on human, but also including non-human suffering. ${ }^{7}$ It is to

6 In his insightful article on "The Cross of Christ in an Evolutionary World," the Danish theologian Niels Gregersen remarks on such traditional viewpoints that they entertain features of God, amongst others as having total and non-negotiable power and sovereignty. He further states that from the understanding of these features, a viewpoint follows that God rewards and punishes according to a rigorous pattern of retribution. For Gregersen, the Augustinian world-view of the 5th century has played an influential role in this regard, reducing all evils and afflictions to an issue of human sin. All evil in the world derives from the perverse wills of rational creatures, and subsequently the evils that befall us are either the result of sin or the result of God's just punishment of sin. See Niels H. Gregersen, "The Cross of Christ in an Evolutionary World," Dialog: A Journal of Theology 40 (2001): 192-207. In this regard, the Dutch scholar Eep Talstra rightly poses the question of whether the concept of God as a God of wrath who makes his people suffer, could ever be generalised into a picture that modern theology could continue to work with. He proposes that we should distantiate ourselves from that picture. He suggests that the approaches of some African theologians are helpful in that they rather begin with the questioning of the role of people and their religion in a context of suffering. See Eep Talstra, "Exile and Pain: A Chapter from the Story of God's Emotions," in Exile and Suffering (ed. Bob Becking and Dirk Human; Leiden: Brill, 2009), 161-180.

7 I will not address specifically in my exposition the important contemporary broadening of suffering that engages the whole of creation, especially non-human suffering. See as an influential example, Christopher Southgate, The Groaning of 
make systematic-theological work of what the South African Old Testament scholar Francis Klopper in Lamenting the Loss of Lament, the Language for Our Times, describes thus:

Traditional Christian responses do not serve those caught in the grip of suffering well, as they are based on doctrines of God that do not correspond with people's real-life experiences. The theodicy problem has long been recognised as a dilemma in Christian theology... ${ }^{8}$

Alternatively, as the Dutch Old Testament scholar Eep Talstra in his exploration of the story of God's emotions, explicitly states, it is mostly in Northern theological approaches that the history of God and humans is seen as ending in tragedy, whereas postcolonial African theologians speak of hope. He explains that, "The reason for hope is the biblical speech about God who is beyond the dilemma, a God who refuses to be made hostage of the mechanism of evil and punishment." 9

To take on this dilemma and to move beyond it imply addressing:

- The tension with traditional Christian responses that do not serve those caught in suffering given their justification by doctrines of God that do not correspond with people's real-life experience, and

- The deep search for credible hope (or to put it differently: A witness to a God worthy of worship, and hope with integrity).

I turn to the Psalter as a reference point in addressing the proposed dilemma. The important pre-question that has to be motivated, is why do we focus specifically on the Psalter?

Creation: God, Evolution, and the Problem of Evil (Louisville: Westminster John Knox Press, 2008). Denis Edwards supports Southgate's viewpoint with the following convincing commentary and theological statement: "How do we think about the final transformation of 'all things', when all things include plants, insects, and animals? Some medieval thinkers thought the 'all things' applied to human beings and to the universe of matter, but not to plant and animal life. But this does not represent the richness of the Christian tradition found in the Scriptures, and in theologians like Irenaeus. It does not do justice to contemporary science, which cannot isolate humans from their evolutionary and ecological relationships. In my view it also does not do justice to the love of God that embraces the whole creation, or to the universal saving will of God." See Denis Edwards, "Christopher Southgate's Compound Theodicy: Parallel Searchings," Zygon 53 (2018): 687.

8 Frances Klopper, "Lamenting the Loss of Lament, the Language for Our Times," in Exile and Suffering (ed. Bob Becking and Dirk Human; Leiden: Brill, 2009), 233246.

9 Talstra, "Exile and Pain," 174. 


\section{HUMAN SUFFERING BEFORE GOD: THE PSALTER}

To motivate the Psalter as my vantage point for considering the question on suffering is fortunately rather easy. In the introduction to his commentary on the Psalms, the Old Testament scholar Arthur Weiser notes that the Psalms is one book in the,

...Old Testament which the Christian community found the easiest one to approach in a direct and personal way. The writers of Christian hymns have drawn from the inexhaustible well of the psalms at all times... From the very beginning of Christianity... right up to the present-day public worship has continually created and cultivated a particular intimate relationship of the worshipping congregation to the psalms... Apart from its use in public worship it also serves as a means of individual edification, as the foundation for family worship, as a book of comfort, as a book of prayers, and as a guide to God in times of joy and affliction. It is hardly possible to grasp, and not easy to overestimate, the strength which has been derived from the psalms in this way, and the way in which they have shaped the history of individual piety. ${ }^{10}$

Weiser subsequently quotes the 16th century Reformer Martin Luther's validation of the psalms from the second Preface of the German Psalter in which he beautifully writes that in the Psalter, we "look into the hearts of all the saints," comparing it to a garden with all sorts of flowers that convey "thoughts about God and his mercy." He asks, where else would one find,

words expressing sorrow more deeply and picturing its misery and wretchedness more tellingly than the words that are contained in the psalms of lament? ... And the very thing is that they speak such words about God and to God... This explains ... why the Psalter is the favourite book of all the saints...

Luther calls the Psalter a "clear, pure mirror" in which you will find yourself, and the true "know thyself" and "God himself and all his creatures..."11

The "mirror" into which we look presents many and different voices about suffering. Suffering, although itself an elusive concept to define and delineate, ${ }^{12}$

10 Arthur Weiser, The Psalms (London: SCM Press, 1962), 19.

11 Weiser, The Psalms, 20.

12 It is necessary, in explicating the question of suffering, to qualify from the onset any reference to suffering, that is, suffering within a context of natural disasters, suffering because of wrongdoing either by myself or by being the victim of wrongdoing by others, or suffering because of an inexplicable occasion or series of events (tragedies). At the same time, one has to acknowledge that the biblical voices on suffering - for example, in the Old Testament - present themselves in very different trajectories within prophetic, wisdom, historical, and Psalter literature. 
can perhaps be best summarised in the Psalter ${ }^{13}$ by an indication of its most important thematic emphases of the causes and /or nature of suffering:

- $\quad$ Sin, apostasy and disobedience $(5 ; 25 ; 32 ; 51 ; 69 ; 78 ; 90)$

- $\quad$ Loneliness and worry $(25 ; 31 ; 69 ; 88 ; 142 ; 143)$

- $\quad$ Acts of others $(4 ; 17 ; 22 ; 35 ; 55 ; 64 ; 109 ; 140)$

- $\quad$ Silence or inactivity of God $(6 ; 22 ; 39 ; 43 ; 88 ; 102)$

- $\quad$ Anger of God $(6 ; 27 ; 38 ; 44 ; 60 ; 74 ; 78 ; 85 ; 88 ; 102)$

- $\quad$ Forgetfulness of God $(13 ; 77)$

- $\quad$ As a process of cleansing and purification $(18 ; 19 ; 40 ; 51 ; 119)$

- $\quad$ As alienation (also in some texts depicted as death) from God (22; $42 ; 80 ;$ $88 ; 137)$.

My list of emphases and the text indications can surely be expanded and qualified more finely. It does not lay any claim to being exhaustive. To deepen and broaden the significance of these emphases, the historical contexts and their respective interpretative frameworks should be explored individually. If, for example, the setting of a psalm is in an exilic/post-exilic context, new insights have to be taken into consideration ${ }^{14}$ (e.g. that those in exile did not have it so bad after all; or that the suffering has to do not with their circumstances as such in the first place, but with the impossibility of forgetting Jerusalem and singing a song from Zion, as in Ps 137). My basic point is that there are so many dimensions to the psalms such as communal and individual, ${ }^{15}$ in the various contexts of responses to suffering. In the one context, the psalmist calls God to account (why does God not act or is silent?) and in another context, calls on God for aid and relief (individually but also collectively), pleading for liberation from

13 The South African Old Testament scholar Hendrik Bosman draws a very similar explanatory list of the different ways in which suffering is depicted in Isa 40-55. See Hendrik Bosman, "Myth, Metaphor or Memory? The Allusions to Creation and Exodus in Isaiah" in Exile and Suffering (ed. Bob Becking and Dirk Human; Leiden: Brill, 2009), 77.

14 See the argument by Bosman, "Myth, Metaphor or Memory?" 77. The same point is made earlier by the German Old Testament theologian Von Rad. See Gerhard von Rad, Old Testament Theology (Vol. 1; London: SCM, 1975), 283, 355ff.

15 Von Rad carefully qualifies our understanding of "individually," saying that the personal element is only expressed in a considerable diminished way, in cultic and conventionalised concepts and phraseology. He adds further that, "It could perhaps be said that even in these prayers, for all their wonderful intimacy, the individual has still not found his way to a self-consciousness or an immediate unrestricted selfpresentation" (Von Rad, Old Testament Theology, 399). 
death $;{ }^{16}$ calls on God not to act in anger and praises ${ }^{17}$ God for not acting in anger; calls on God not to remember the sinful conduct of the believer or the nation, and then again calls on the nation to remember God as of its reason for being. In other passages, it puts tears into words of alienation and worry and loneliness before God but the very same tears feed a declaration of trust and so forth. Interestingly, I could not pick up any clear traces of either a strong or a weak (explicit or implicit) theodicy, as we find in Job for example. It is as if the most sufferers $^{18}$ speak/plea/complain/pray /confess with a double voice. The experience is shared, on the one hand, and on the other hand, it is countered with either words of praise or of trusting and longing for the (still outstanding) realisation of God's justice or of God's goodness and/or faithfulness. ${ }^{19}$

If I thus take this very brief exposition of suffering within the Psalter and embed these very dimensions in an evolutionary perspective, would it assist me in challenging contemporary traditional (read: superficial) Christian viewpoints on suffering, and if yes, how? I therefore turn to a brief overview of an evolutionary approach.

\section{An evolutionary approach to suffering: a proposal}

1a Relating science and theology "After Darwin"

If I take as a vantage point and as broadest reflective context the remark by the American theologian John Haught that if the idea of God is to arouse our instinct to worship, it cannot be smaller than the universe that science has made conspicuous to us, especially after Darwin, ${ }^{20}$ how can the "bigger" world of worship then be related to the "smaller" world of the sciences? Additionally, how - if an evolutionary approach can be insightfully convincing and helpful - can it be done? To answer these questions, a few preliminary remarks must suffice.

Within contemporary science-theology discourses and in the last 160 years, evolutionary theory has developed far beyond Charles Robert Darwin (1809-1822) and his On the Origin of Species (1859) and Descent of Man

16 For Israel, according to Von Rad, Old Testament Theology, 387, death's domain reached far into the realm of living. Weakness, illness, imprisonment and oppression by enemies are a kind of death.

17 Interestingly Von Rad, Old Testament Theology, 357 explains that the verb "to praise" properly means "to confess," "to accept" so that sometimes one can actually talk about Israel's doxologies of judgment.

18 I use the word "most" because there are more than one exception to this remark. In Ps 88 , for example, there is no thanksgiving or vow of praise, only anger and protest. See Klopper, "Lamenting the Loss of Lament," 243.

19 In his discussion of Ps 137, Becking, "Does Exile Equal Suffering?", 199 remarks that, in his opinion, a dichotomy between a "God of vengeance" and a "God of love" is an obsolete construction based on reductionistic, one-dimensional image of YHWH.

20 John Haught, God after Darwin (Boulder: Westview Press, 2008), ix. 
(1871). ${ }^{21}$ From there the term, "After Darwin," came into use. However, Darwin has gifted us - in the words of John Haught ${ }^{22}$ that I support - with an account of life whose depth, beauty, and pathos expose us afresh to the raw reality of the sacred and to a resoundingly meaningful universe. However, it is precisely the "raw reality of the sacred" that was debated furiously in diverse religious circles since the first scientific acknowledgement of evolution as the best explanation for the biological origin of life.

Regarding the questioning of the "raw reality of the sacred," the English theologian Christopher Southgate quotes the biologist David Hull in reference to Darwin's journey to and findings on the Galapagos Islands thus:

What kind of God can one infer from the sort of phenomena epitomised by the species on Darwin's Galapagos Islands? The evolutionary process is rife with happenstance, contingency, incredible waste, death, pain, and horror... Whatever the God implied by evolutionary theory and the data of natural selection may be like, he is not the Protestant God of waste not, want not. He is also not the loving God who cares about his productions. He is not even the awful God pictured in the Book of Job. The God of the Galapagos is careless, wasteful, indifferent, almost diabolical. He is certainly not the sort of God to whom anyone would be inclined to pray. ${ }^{23}$

In contrast to Hull's inference of the almost diabolical Darwinian God, the English Catholic priest Aubrey Moore (1848-1890) declares Darwin a

21 What did Darwin's original theory of evolution entail? According to his theory, all forms of life descend from a common ancestor. The wide array of living species can be accounted for by a process called "natural selection." Members of any given species, by sheer accident, will differ from one another, and from ensuing variety, nature will then "select" only the "fit," those best "adapted to their environmental circumstances, to survive and bear offspring. Over immense periods of time, selection of minute favourable changes in adaptability will bring about countless new and distinct forms of life, including eventually humans. Most scientists support this basic approach of Darwin regarding his ideas on life's common ancestry and the mechanism of natural selection. However, evolutionary biologists and various other fields of reflection on the significance of his contribution, differ on many issues such as the respective roles in evolution of chance, adaption, selection, genes, individual organisms, groups, struggle, cooperation, and competition. To mention but one of many good expositions on Darwinism, see Conor Cunningham, Darwin's Pious Idea (Cambridge: Eerdmans, 2010).

22 Haught, God after Darwin, 2.

23 Southgate, The Groaning of Creation, 7. 
friend, ${ }^{24}$ not a foe with regard to religiosity and the God question. For Moore, we are rather faced with an option:

The one absolutely impossible conception of God, in the present day, is that which represents him as an occasional visitor. Science has pushed the deist's God further and further away, and at the moment when it seemed as if he would be thrust out altogether Darwinism appeared, and, under the disguise of a foe, did the work of a friend. It has conferred upon philosophy and religion an inestimable benefit, by showing us that we must choose between two alternatives. Either God is everywhere present in nature, or he is nowhere. ${ }^{25}$

Sharing the exploration of the former alternative, namely God as being everywhere present in nature and in pursuit of what Moore calls an "inestimable benefit," the most crucial issue at stake, in the words of the Danish systematic theologian Niels Gregersen was:

... (I)f God's way of maintaining and developing the world of creation happens through the means of natural selection, how can the Christian belief in the mercy of God be consonant with the ruthlessness of evolutionary processes? ${ }^{26}$

Although the "raw reality of the sacred" continues to represent the core of the debate, the crucial issue as formulated by Gregersen almost two decades ago has long shifted and has changed dramatically. As was stated earlier, evolutionary theory has developed far beyond Darwin, especially in the interpretative wake of the Human Genome Project (1990-2003) and contemporary discourses on Evolutionary Epistemology (EE) and the Evolutionary Extended Synthesis (EES).

The former, namely EE, has revealed the biological roots of all human rationality. As humans and as embodied personhood who resulted from evolutionary processes, we find that our mental capacities are constrained and shaped by the mechanisms of biological evolution. ${ }^{27}$ Not only does it

24 In the wake of Moore's declaration of Darwin as "friend of religiosity," other scholars have followed. To give but one other example. The American philosopher and sceptic Michael Ruse, who calls himself a conservative atheist, raises the friendship issue in a very different but striking way, saying, "Darwinism, a science which so stresses physical suffering, looks to Christianity, which so stresses physical suffering and the divine urge to master it." See Michael Ruse, Can a Darwinian Be a Christian? The Relationship between Science and Religion (Cambridge: Cambridge University Press, 2001), 131.

25 Aubrey Moore, as quoted in Southgate, The Groaning of Creation, 10-11.

26 Gregersen, "The Cross of Christ," 192 [emphasis by author].

27 Wentzel van Huyssteen, Duet or Duel? (Harrisburg: Trinity Press International, 1998), xiii-iv. Van Huyssteen has developed his viewpoint on evolutionary 
unavoidably lead to the interdisciplinary account, whether in the natural sciences or human sciences, of all of our epistemic activities, but it also leads to the crucial role of a distinctively human imagination as intrinsic evolutionary force. In this responsible manner, the "bigger world" of worship and "smaller world" of the natural sciences, given the shared resources, should and can be related.

Human imagination as evolutionary force represents the core of the latter exciting development far beyond Darwin, namely EES. ${ }^{28}$ "Becoming" and "niche" represent the two key words in EES from our evolutionary history as Homo sapiens. In EES, Darwin's theory has been broadened insightfully such that evolution is not only understood through a variety of lenses but it has also been expounded as much more than the inheritance of genes. Crucial is the following insight:

The variety of lenses and its broadening have unearthed the influential totalising discourses on the insistence of natural selection as a creative force as well as opened up new exciting interpretative anthropological horizons. ${ }^{29}$

Thus, EES revised the classical understanding of Darwin's evolutionary theory in that "becoming human" restrictively entails past fitness, potential and survival mechanisms in which natural selection and sexual selection were taken as the key factors in change and adaptations for evolutionary success over a period of time. Especially the work by the Israeli evolutionary theorist and geneticist, Eva Jablonka and the English natural scientist Marion Lamb, developed in their Evolution in Four Dimensions, argues that apart from genes, three other inheritance systems come into evolutionary play, namely epigenetic, behavioural, and symbolic inheritance. Evolution is now much more than simply the inheritance of genes. Behaviour and behavioural patterns are vehicles of the transmission of information, and its transmission occurs through socially

epistemology and human rationality influentially in his later works such as The Shaping of Rationality: Toward Interdisciplinarity in Theology and Science (Eerdmans: Grand Rapids, 1999); idem., Alone in the World? (Eerdmans: Grand Rapids, 2006); idem., "Human Origins and the Emergence of a Distinctively Human Imagination: Theology and the Archaeology of Personhood," in Verbs, Bones, and Brains: Interdisciplinary Perspectives on Human Nature (ed. Agustin Fuentes and Aku Visala; Notre Dame: Notre Dame Press, 2017); idem., "Human Origins and the Emergence of a Distinctively Human Imagination," in Evolution of Wisdom: Major and Minor Keys (ed. A. Fuentes and C. Deane-Drummond; Center for Theology, Science, and Human Flourishing: University of Notre Dame, 2018).

${ }^{28}$ For the following exposition of EES, I have used and reworked earlier research from Danie Veldsman, "Coming Narratively Face to Face: Evaluating from Our Evolutionary History the Contemporary Risk Factors and Their Conceptualisation within a Technologized Society," Scriptura 119 (2020): 1-12.

29 Ibid., 7. 
mediated learning. Language ensures not only symbolic inheritance, but also the ability to engage in complex information transfer containing a high density of information. ${ }^{30}$ Here emerges a special and distinct human trait, namely the organisation, transferral, and acquisition of information. In short, it is our ability to think and communicate through words and other types of symbols that makes "being human" different. Enough has been said at this point on "becoming human." I turn to the second key word.

With "becoming" as key word for EES, stands the second key word namely "niche construction." From the conviction that the variation on which natural selection acts is not always random in origin or blind to function and as response to the conditions of life, a new heritable variation can arise. In short, organisms are constructed in development, not simply programmed to develop by genes. Consequently, they do not evolve to fit into pre-existing environments but co-construct and co-evolve with their environments. ${ }^{31}$ That is niche construction! In this, humans construct ecological, technical and cultural niches that influence the structure of evolutionary landscapes. ${ }^{32}$ At the very heart of these constructions, lie most probably the most fascinating dimension of "becoming" and "niche" construction as evolutionary force, namely a distinctively human imagination. A few notes from our evolutionary history must suffice as background to this important and most determinative dimension of "being human," namely imagination.

In the so-called Pleistocene Period, that is, from about 2.5 million to 12 000 years ago, we find a significant evolvement of increasing complexities regarding culture and social traditions, tool and manufacture, trade and the use of fire, but even more, enhanced infant survival, predator avoidance, increased habitat exploitation and information transfer via material technologies. ${ }^{33}$ Van Huyssteen insightfully summarises the implications of Augustin Fuentes' article, "Human Evolution, Niche Complexity, and the Emergence of a Distinctively Human Imagination," thus:

All of these increasing complexities are tied directly to a rapidly evolving human cognition and social structure that require greater cooperative capabilities and coordination within human communities. Thinking of these developments as specific outcomes of a niche construction actually provides a mechanism, as well as a context, for the evolution of multifaceted response capabilities and coordination within communities. ${ }^{34}$

30 Jablonka and Lamb, 193-231.

31 Fuentes, 13ff.).

32 Ibid., 14).

33 Van Huyssteen, "Human Origins," (2018), 28.

34 Ibid., 28. 
Further,

(T)he emergence of language and a fully developed theory of mind with high levels of intentionality, empathy, moral awareness, symbolic thought, and social unity would be impossible without an extremely cooperative and mutually integrated social system in combination with enhanced cognitive and communicative capacities as our core adaptive niche. ${ }^{35}$

The key part of our evolutionary niches, and perhaps the best explanation for why our species succeeded while all other hominins went extinct, is a distinctively human imagination as intrinsic evolutionary force. There is a naturalness not only to human imagination but also to religious imagination and it makes our engagement with the world in some ways truly distinct from any other animals. Van Huyssteen insightfully concludes:

Now existing in a landscape where the material and social elements have semiotic properties, and where communication and action can potentially be influenced by representations of both past and future behaviour, implies the possession of an imagination, and even something like hope, i.e., the expectation of future outcomes beyond the predictable. ${ }^{36}$

If we are then prompted from these evolutionary insights to explore imaginatively new interpretative landscapes and horizons with regard to the question of suffering, we will have to identify our "old" conceptual entrapments and pre-scientific anachronisms ${ }^{37}$ to enable us to move beyond them and leave them behind us. It is, in the words of the Australian eco-theologian Denis Edwards, to "start from the kind of universe we find ourselves, that is, to start from the fact that this is the way things are: we are evolutionary creatures in an evolutionary universe, and this is the package deal." 38 It is a package deal in which the evolutionary re-conceptualisations are undertaken as an interpretative stream, that is, re-conceptualisations consisting of a number of dimensions that must all to come to play and flow together in bringing about meaningfulness. In my opinion, the interpretative stream will ultimately unmask any effort to construct any kind of theodicy as existentially inappropriate. Existentially inappropriate? Yes, since as will be argued in what follows, that all these

35 Ibid., 29.

36 Ibid., 29-30.

37 See Christopher Southgate, "Does God's Care Make Any Difference? Theological Reflection of the Suffering of God's Creatures," in Christian Faith and the Earth: Current Paths and Emerging Horizons in Ecotheology (ed. Ernst Conradie, Sigurd Bergmann, Celia Deane-Drummond and Denis Edwards; London: Bloomsbury, 2014), 97-114.

38 See Edwards, “Christopher Southgate's Compound Theodicy,” Zygon 53 (2018), 683. 
impressive efforts to weave together theodicies are, on the one hand, permeated by an intellectual universalist longing to control and to transcend the limitations of being human and on the other hand, suffer greatly from anthropological amnesia, that is, forgetting and subsequently ignoring the fact that we exist as vulnerable embodied persons in our contextual particularities. Therefore, my proposal that we, in light (and darkness!) of the little we see and know, and the lots we do not even know and that we do not see, do away with formulating theodicies and replace them as vulnerable embodied persons that live in an evolutionary world with, what I would call, cognitive-affective re-appraisals in the moments of suffering. Such re-appraisals will be an effort to protest in and against suffering so that it does not have the last word. That will be my last word in this exposition, but before then we must turn to the package deal in which the "bigger" world of worship and the "smaller" world of the sciences are connected (Haught), connected in the spirit of the words of wisdom of Christopher Southgate, which I theologically endorse with my whole heart: "An evolving creation was the only way in which God could give rise to the sort of beauty, diversity, sentience and sophistication of creatures that the biosphere now contains." 39

1b Unfolding reconceptualised perspectives on our world, God, being human, and vulnerability ${ }^{40}$

As evolutionary creatures in an evolutionary universe whose story is far from over, we will have to leave behind us, because of the package deal we find ourselves in, a static worldview; views of an Almighty God that is distant and uninvolved with God's creation and creatures; static views of "being human"; and sin as foundational explanation for the way the world is. By accepting the package deal we find ourselves in, we will have to embrace interpretatively a dynamic worldview; views of a kenotic and co-suffering God for whom creation and its creatures matters; views of embodied vulnerable personhood; and the costs of the evolutionary way the world is. Brief and broad sketchy notes on each one must suffice.

Firstly, on a dynamic worldview, we can say that a dynamic worldview flows from two very different (methodological) sources, namely cosmology and evolutionary biology - both seemingly evolving through autonomous emergent processes. The former entails the acknowledgement of an observable universe

\footnotetext{
39 See Southgate, The Groaning of Creation.

40 My own scholarly struggle to find words and to make sense of the deep and ever ongoing escaping challenge of suffering has been strongly influenced by Christopher Southgate. Some of his deep insights and sensitive formulations of a compound theodicy underlie much of the following exposition.
} 
back to within the first second of its existence 13.7 billion years ago. ${ }^{41}$ It is a universe that is expanding, cooling and growing in complexity according to its own laws. The latter sees all life on Earth evolving from its origin 3.8 billion years ago through processes that include contingent events, natural selection in terms of niche construction and the eventuation of multi-dimensional inheritance (EES). In terms of our biblical creation stories, we can say, in a very qualified hermeneutical sense, that we find ourselves on the sixth day of a groaning ${ }^{42}$ creation.

Secondly, on views of God, these would be of God who has created from nothing outside Godself, that is, from no other reason outside of God but from God's inner loving imagination. A kenotic God who has limited Godself in dynamic relationships with God's creation and creatures; a God that respects God's own handiwork and the integrity and dignity of God's creation and creatures; a God that consequently does not intervene with natural processes. It is a God that respects the autonomy of God's creatures, ${ }^{43}$ a dynamic God that is there for us in each moment of creaturely flourishing and prosperity, but also as co-sufferer in each moment of our adversities, ill luck and failures - and especially in taking on Godself all the costs (of suffering) that come with evolution in the cross of Jesus Christ. The cross is the epitome of divine compassion. It foundationally constitutes and represents the empathic moment of taking responsibility for all of creation and its creatures to make a hopeful difference in the resurrection for the whole of creation, but especially for those who have become victims of suffering. It is a hopeful transformational difference that Southgate describes as the "hope that suffering creatures will experience a participation in God's eschatological fulfillment." 44

Thirdly, on being human, we are humans of flesh and blood, woven biologically together in vulnerability with a nervous and immune system. The former represents our electrical wiring. The wiring consists of a collection of nerves and cells that are responsible for the transmission of signals between

41 The core of the following formulations comes from Edwards, "Christopher Southgate's Compound Theodicy," 683.

42 This is the emphasis by Southgate, The Groaning of Creation, 17, in appropriating the text of Romans 8:19-22. He, however, makes clear that he does not imply in any way that Paul had any evolutionary awareness. He does state that whereas Paul was thinking in terms of "bondage to decay" resulting after sin of the first humans, we must part company with a picture of a fall from a primordial paradise.

43 Edwards, "Christopher Southgate's Compound Theodicy," 683, refers to the following insightful formulation of the Dutch philosopher and theologian Rudi Te Velde in his exposition of the viewpoint of Aquinas on God: "God creates in such a way that creation is 'set free' in its own natural being."

44 The formulation of Southgate's viewpoint and emphasis is by Edwards, "Christopher Southgate's Compound Theodicy," 681 
different parts of the body. Our very sophisticated nervous system makes us, amongst others and importantly, in relation to this exposition on suffering, to experience pain. ${ }^{45}$ The latter, namely our immune system represents our bodily defence mechanism that protects us against potentially harmful organisms (bacteria, viruses. fungi, protozoa and parasites) in the environment. However, we also have arms and legs to fight off or flee from those that threaten us. We are thus at the same time biologically and physically equipped to experience pain and to be able to fight off harmful intruders. The very same nerves (with blood) are the basic components of our sensory system that enables interaction (to see, hear, touch, feel, smell and balance) with our environment, that is, to perceive the world in which we find ourselves. Given our biological make-up, we perceive the world in an inseparable mix of knowing and feeling (that is, cognitivelyaffectively) ${ }^{46}$ from the creative spark (Augustin Fuentes) within us, that is, imagination, and driven by senses of belonging (attachment) and free will (ability to choose). With it all comes the naturalness of religious imagination and, ultimately, our religious anthropological status as image of God and coredeemers with God.

Fourthly, on sin and grace, sin is seen as a part and parcel of our experiential realities and our diverse relationships, but not as the foundational determinative force of the way that our universe is woven together. For that, we as human beings will have to take full responsibility. The cosmic significant cross of Christ also includes the invitation to find and accept forgiveness. It however does not imply that specific experiences of suffering cannot or must not be related to sin. Its relational connectedness (sin - suffering) and integrity come from the concrete and contextual unfolding narrative in its experiential multidimensionality. On grace, I find my wording with Haught' $s^{47}$ exploration of its meaning in an evolutionary context. According to Haught, grace, as divine love, finds as its deepest expression, the resistance, the holding back of forcing oneself

45 See Gregersen, "The Cross of Christ," 197-198, and Southgate, The Groaning of Creation, 7-8, respectively for their view of pain as necessary concomitant of a richer experience of the world of higher animals (that is: pain is the price to be paid for having a highly sensitive nervous system), and death as a thermodynamic necessity (that is: death is the price to be paid for living as highly complex creatures far beyond thermodynamical equilibrium).

46 The emphasis on the cognitive-affective dimension of being human and the manner in which it determines our relating to and interaction with our realities, is crucial to acknowledge in any approach to the question of suffering. See Danie Veldsman, "With Reasons of the Heart before God: On Religious Experience from an Evolutionarytheological Perspective," NGTT 55 (2014): 425-441. https://ngtt.journals.ac.za/pub/issue/view/28.

47 See Haught, God after Darwin, 43. Haught insightfully mentions in this regard the prayer of the 15th century German philosopher and theologian Nicholas of Cusa: "How could you give yourself to me unless you had first given me to myself?" 
upon the beloved. Instead, it longs for the beloved to be self-actualising, so as to become more and more "other" or differentiated. Along with its nurturing and compassionate attributes, love brings with it a longing for the independence of that which is loved. Without such letting be of its beloved, the dialogical intimacy essential to a loving relationship would be impossible. In short, it implies a loving relationship of "letting the world be itself." Only a relatively independent universe, a universe allowed to be itself, could be intimate with God.

How then can the significance of the Psalter be embedded meaningfully in these evolutionary views of a dynamic universe, of God, of being human, of sin and of grace?

\section{$2 \mathrm{a} \quad$ In the moment of suffering}

For those who find (or lose) themselves, ${ }^{48}$ that is, as victims in the moment of suffering, it represents a rupture, a tear in the fibre of their lived reality of ultimate meaning. The rupture represents the experiential moment for the believer of the eclipse of God - the momentary feeling of being deserted by God (for example, Ps 22:1). As response, these moments of rupture in which the heart of the victim is "emptied' and/or broken, are expressed in extremely diverse personal ways. Over time, a personal narrative, in most cases, is shaped in which the experiences of suffering are captured. Experiences in which the sufferer explicitly or implicitly protests against "staying" a victim of the traumatic and unearthing event - a short-circuit of my existential wiring - which threatens to marginalise the believer's wholeness or understanding of meaningfulness. Of these diverse moments, if reflected from our creative sparks (read: imagination), within a context of Christin worship and belief, the Psalter is our best biblical example. ${ }^{49}$ I agree fully with Martin Luther that these moments of protest, of

48 Am I writing here merely from a viewpoint of intellectual and academic-theological curiosity? No, I write from an own experience of intense personal trauma after the assassination of my uncle, Prof Johan Heyns on the evening of 5 November 1994 in his home and in front of his wife and grandchildren. He was not only my theological mentor in Dogmatics at the University of Pretoria, but a very close older colleague and friend who took me as a young inexperienced student and later as a colleague with open arms into his intense theological-societal journey of seeking the will of God for the church, justice in our South African society, and good Reformed theology. How well I remember his strong disdainful rejection of anything that smells of evolutionary thought in my developing theological interests - but at the same time, his surprisingly calm acceptance of the theological direction that I was venturing into and eager to explore.

49 There are of course many other "contemporary psalms" that I immediately can think of especially one that I find intensely heart gripping, that is, the prayer of the Dutch woman Etty Hillesum (1914-1943). She was killed at the age of 29 in Auschwitz concentration camp. Just more than a year before her killing, she writes on the 12 July 1942, a Sunday morning prayer in which she longs for and pleads before God: 
"coming to terms and heart" in which a personal narrative is shaped, are embedded in a con-"text" that I would like to briefly elaborate on and label as cognitive-affective re-appraisal. ${ }^{50}$

For me, cognitive-affective re-appraisal (c-aRE) entails the existential process in which or movement within the victim that seeks to find a meaningful life again beyond the suffering - in whatever manner - as protest not to be crushed/destroyed/annihilated by the experience of suffering. It is to consciously step back (or to be assisted to step back) from the immediacy of the very specific emotional moment (read: affective), to think through (or to be assisted to reflect on) his or her thoughts on/interpretation (read: cognitive) of the moment of suffering - and to make adjustments so that the emotional outcomes are changed or directed towards healing or wholeness. In this process or movement, the reading or reciting of the Psalter, embedded in the sensitive thinking through of the moment of suffering from evolutionary insights, can bring about, even in moments of tragic incomprehensibility, hopeful directives towards healing or wholeness. In this sense, the evolutionary (cognitive-affective) reframing of the moment of suffering, as captured in the narrative of the sufferer as a protest not to remain a victim, becomes realised grace. This grace ultimately eventuates life, not clear-cut or finished answers. It is to experience as vulnerable embodied

"Dear God, these are anxious times. Tonight, for the first time I lay in the dark with burning eyes as scene after scene of human suffering passed before me. I shall promise You one thing, God, just one very small thing: I shall never burden my today with cares about my tomorrow, although that takes some practice. Each day is sufficient unto itself. I shall try to help You, God, to stop my strength ebbing away, though I cannot vouch for it in advance. But one thing is becoming increasingly clear to me: that You cannot help us, that we must help You, God, in ourselves. And perhaps in others as well. Alas, there doesn't seem to be much You Yourself can do about our circumstances, about our lives. Neither do I hold You responsible. You cannot help us, but we must help You and defend Your dwelling place inside us to the last." Quoted in Marjo Korpel and Johannes de Moor, The Silent God (Leiden: Brill, 2011), 287.

50 My choice of the term "re-appraisal" comes from the discussion of Bethany Sollereder of Christopher Southgate's viewpoint on suffering as reflected in his "compound theodicy" in which she insightfully and critically argues for a "compassionate theodicy." Her reference is to the practice of "re-appraisal" which is foundational to cognitive behavioural therapy. I use the term in line with her definition of "re-appraisal" as a process of re-interpreting the meaning of a stimulus that subsequently leads to a change in one's emotional response to it. My coinage of the concept of "cognitive-affective re-appraisal" is based on her explanation of the nature of the therapy in which people are trained to step back from the immediacy of emotional situations, think through their cognitive reactions and adjust them in order to change the emotional outcomes of the situation. See Bethany Sollereder, "Exploring Old and New Paths in Theodicy," Zygon 53 (2018): 734-735. 
persons within my personal concrete moment of suffering a touch or participatory glimpse of and in God's eschatological fulfilment. ${ }^{51}$

\section{CONCLUSION}

The evolutionary package deal in which we creatively mirror (Luther) or find (or lose!) ourselves and in which we as vulnerable embodied persons of flesh and blood are deeply challenged - whether by personal, societal, systemic, or natural events - in the very different moments of suffering, can be taken on and directed through c-aRE. Through c-aRE, the words of Farrer with which I began my exposition on a "poor limping world" and the "thorn" in our paws, can be read and understood in a different sense - in a different sense when embedded in an evolutionary sense-making framework of our affective-cognitive biological make-up and the naturalness of our creative spark. In c-aRE, grace can be realised and experienced concretely as the victim moves (or is assisted to move) to healing and wholeness. As an event of re-appraisal, it realises through our feelings and thoughts the existential participation in the words of Psalm 126:56:

Those who sow in tears will reap with shouts of joy. They go along weeping and sow their seed; they come home with shouts of joy and bring their sheaves with them.

\section{BIBLIOGRAPHY}

Anon. New World Encyclopaedia. http://www.newworldencyclopedia.org/entry/ Theodicy. Access Date: 4 April 2020.

Balfour, Daylon. "Second-personal Theodicy: Coming to Know Why God Permits Suffering by Coming to Know God Himself." International Journal for Philosophy of Religion 88 (2020): 287-305.

Becking, Bob. "Does Exile Equal Suffering? A Fresh Look at Psalm 137." Pages 183202 in Exile and Suffering. Edited by Bob Becking and Dirk Human, Leiden: Brill, 2009.

Bosman, Hendrik. "Myth, Metaphor or Memory? The Allusions to Creation and Exodus in Isaiah". Pages 71-82 in Exile and Suffering. Edited by Bob Becking and Dirk Human, Leiden: Brill, 2009.

Cunningham, Conor. Darwin's Pious Idea. Cambridge: Eerdmans, 2010.

Denys, Damiaan. "Tien geboden." Trouw. No Pages. Accessed 4 April 2020. Online: https://www.trouw.nl/leven/ filosoof-damiaan-denys-het-coronavirus-is-eengezonde-correctie-op-onze-megalomane-levensstijl.

Edwards, Denis. "Christopher Southgate's Compound Theodicy: Parallel Searchings." Zygon 53 (2018): 680-690.

51 My formulation of this point is strongly influenced by Southgate's viewpoint of a compound theodicy in which eschatological fulfilment represents one of his four theological positions. 
Farrer, Austin. Love Almighty and Ills Unlimited: An Essay on Providence and Evil, Containing the Nathaniel Taylor Lectures for 1961. London: Collins, 1962.

Fuentes, Agustin and Deanne-Drummond (eds). Evolution of Wisdom: Major and Minor Keys. Center for Theology, Science, and Human Flourishing: University of Notre Dame, 2018.

Gregersen, Niels H. “The Cross of Christ in an Evolutionary World.” Dialog: A Journal of Theology 40 (2001): 192-207.

Haught, John. God after Darwin. Boulder: Westview Press, 2008.

Jablonka, Eva and Lamb, Marion J. Evolution in Four Dimensions: Genetic, Epigenetic, Behavioral, and Symbolic Variation in the History of Life. London: MIT Press.

Klopper, Frances. "Lamenting the Loss of Lament, the Language for Our Times." Pages 233-246 in Exile and Suffering. Edited by Bob Becking and Dirk Human, Leiden: Brill, 2009.

Korpel, Marjo and Johannes De Moor. The Silent God. Leiden: Brill, 2011.

Leibniz, Gottfried W. Essays on the benevolence of God, the freedom of man and the origin of evil, (1710) http://www.newworldencyclopedia.org/entry/Theodicy.

Phillips, Dewi Z. The Problem of Evil and the Problem of God. London: SCM Press, 2004.

Pinnock, Sarah K. Beyond Theodicy. Albany: SUNY Press, 2002.

Ruse, Michael. Can a Darwinian Be a Christian? The Relationship between Science and Religion. Cambridge: Cambridge University Press, 2001.

Sollereder, Bethany. "Exploring Old and New Paths in Theodicy." Zygon 53 (2018): 727-738.

Southgate, Christopher. The Groaning of Creation: God, Evolution and the Problem of Evil. Louisville: Westminster John Knox Press, 2008.

"Does God's Care Make Any Difference? Theological Reflection of the Suffering of God's Creatures." Pages 97-114 in Christian Faith and the Earth: Current Paths and Emerging Horizons in Ecotheology. Edited by Ernst Conradie, Sigurd Bergmann, Celia Deane-Drummond and Denis Edwards. London: Bloomsbury, 2014.

Swinton, John. Raging with Compassion: Pastoral Responses to the Problem of Evil. Grand Rapids: Eerdmans, 2007.

Talstra, Eep. "Exile and Pain: A Chapter from the Story of God's Emotions." Pages 161-180 in Exile and Suffering. Edited by Bob Becking and Dirk Human. Leiden: Brill, 2009.

Van Huyssteen, Wentzel. Duet or Duel? Harrisburg: Trinity Press International, 1998. The Shaping of Rationality. Toward Interdisciplinarity in Theology and Science. Grand Rapids: Eerdmans, 1999.

Alone in the World? Grand Rapids: Eerdmans, 2006.

"Human Origins and the Emergence of a Distinctively Human Imagination: Theology and the Archaeology of Personhood." Pages 165-189 in Verbs, Bones, and Brains. Interdisciplinary Perspectives on Human Nature. Edited by A. Fuentes and A. Visala. Notre Dame: Notre Dame Press, 2017.

"Human Origins and the Emergence of a Distinctively Human Imagination." Pages 25-40 in Evolution of Wisdom: Major and Minor Keys. Edited by A. Fuentes and C. Deane-Drummond. Centre for Theology, Science, and Human Flourishing. Notre Dame: University of Notre Dame, 2018. 
Veldsman, Danie. "With Reasons of the Heart before God: On Religious Experience from an Evolutionary-theological Perspective." Nederduitse Gereformeerde Teologiese Tydskrif 55 (2014): 425-441.

. "God's Spirit (of Wisdom) Has Been Sent into the World, not Covid-19: A Contextual Systematic-theological Perspective." HTS Theological Studies 76 (2020): 1-2.

_ "Coming Narratively Face to Face: Evaluating from Our Evolutionary History the Contemporary Risk Factors and Their Conceptualisation within a Technologized Society." Scriptura 119 (2020): 1-12.

Von Rad, Gerhard. Old Testament Theology. Vol. 1. London: SCM, 1975.

Weiser, Arthur. The Psalms. London: SCM Press, 1962.

Wright, Nicholas T. Evil and the Justice of God. Downers Grove: IVP, 2006.

Daniël P. Veldsman, Department of Systematic Theology and Historical Theology, Faculty of Theology and Religion, University of Pretoria. Email: danie.veldsman@up.ac.za. ORCID: https://orcid.org/0000-0002-8734-2171. 